\title{
Assessment of Nutritional and Microbiological Properties of Biscuit Supplemented With Moringa Oleifera Seed Protein Concentrate
}

\author{
T.A. Aderinola*, O. E. Lawal, T.D. Oluwajuyitan \\ Department of Food Science and Technology, Federal University of Technology, Akure, P.M.B. 704, Akure, \\ Nigeria \\ E-mail: taaderinola@futa.edu.ng (Corresponding author)
}

Received: 17 March 2020; Accepted: 3 April 2020; Available online: 15 May 2020

\begin{abstract}
The aim of the study was to evaluate the impact of Moringa oleifera seed protein concentrate supplementation on the nutritional composition of biscuit. Biscuit was supplemented with $M$. oleifera seed protein concentrate at 2, 4 and $6 \%$ and evaluated for the proximate composition, amino acid profile, mineral element composition, microbiological properties and sensory qualities. The proximate composition result showed that the biscuits contained: $8 \%, 58.92 \%, 6.45 \%, 0.32 \%, 0.97 \%$ and $26.32 \%$ moisture, crude protein, crude fat, crude fiber, ash and carbohydrate, respectively. The essential amino acids were lysine (6.57\%), leucine (6.02\%), tryptophan (5.23\%), valine $(5.20 \%)$, phenylalanine $(4.25 \%)$, threonine $(4.10 \%)$, histidine $(4.03 \%)$, isoleucine $(3.34 \%)$ and methionine (2.94\%). The proximate composition results showed a slight but progressive increase in crude protein content due to the supplementation while the overall quality acceptability did not show any statistically significant difference among the biscuit samples. The microbiological result also revealed that the biscuits were safe and the level of detection were within the safe range for baked products. It was concluded that supplementation of biscuit with $M$. oleifera seed protein concentrate is safe and the consumption of the biscuits may support growth and development of children who are the major consumers.
\end{abstract}

Keywords: Moringa oleifera seed; Supplementation; Biscuit; Amino acids; Nutritional composition.

\section{Introduction}

Biscuits constitute one of the major baked products that are globally recognized and consumed. However, the continued consumers' demand for quality food products that are convenient, safe, tasty and of adequate nutrition [1] has resulted in the supplementation of wheat flour with other flours [2-4] leading to production of a baked product with a more pronounced nutritional and health benefits. These foods, including baked products are called functional foods due to the health benefits derivable from the consumption of such foods in addition to the normal supply of nutrition. The common health benefits such as antihypertensive, antidiabetic, free radical scavenging abilities ascribed to the consumption of such foods are due to the different bioactive components (polyphenol, protein, peptides) in the added food ingredients.

Wheat flour is a basic ingredient in biscuit production because of its gluten protein, which are not present in the flour of other cereals [5]. Protein quality of wheat is inferior to that of most cereals and this has resulted in a number of efforts to supplement wheat flour with other protein rich flour [3,6-9]. A major portion (50 to 60\%) of the minerals and vitamins in wheat grain is found in the bran, aleurone, and germ. These grain components are partially or totally removed during milling. Hence, the inferior nutritional quality of wheat flour gets pronounced further through the flour refining process [3]. Biscuit is a baked product produced from wheat flour which is a high energy food, rich in carbohydrate and fat [10] but low in other nutrients such as protein, mineral and vitamin $[11,12]$. Furthermore, the nutritional quality of biscuit is low because of the inferior nutritional compositions of other ingredients (fat, salt, sugar, flour etc) used during preparation. The ingredients mostly provide fats and simple carbohydrate which can contribute to rapid fluctuation in blood sugar level and increased body weight. In order to increase the nutritional composition of baked products, many studies have investigated several potential alternatives to wheat flour with other supplementary flour [3,6-9].

One of the major nutritional challenges in developing countries and especially Nigeria is malnutrition which is due to inadequate consumption of protein [13]. A potential and convenient means to reduce this challenge is to supplement baked products such as biscuits with protein since they are commonly consumed among people especially by children. Moringa oleifera seed is an underutilized but important food source with high crude protein content up to $50 \%$ on dry weigh basis [14]. 
The author's previous studies had reported the nutritional and bioactive properties of $M$. oleifera seed proteins [15-17] and its potential application in food system [18]. However, no previous studies has reported on the utilization and nutritional properties of biscuits supplemented with M. oleifera seed protein. Therefore, the aims of the study were to evaluate the nutritional and microbiological properties of biscuits supplemented with Moringa oleifera seed protein concentrate.

\section{Material and methods}

\subsection{Source of materials}

Moringa oleifera seeds and wheat flour were bought from King’s Market, Ondo state, Nigeria.

\subsection{Production of moringa oleifera seeds protein concentrate flour}

Moringa oleifera seed protein concentrate was obtained using a previously described method [17]. Defatted flour samples was dispersed in $0.1 \mathrm{M} \mathrm{NaOH}(1: 20$, w/v), mixed for $1 \mathrm{~h}$ and centrifuged at room temperature (3500rpm for 30min). The supernatant was adjusted to $\mathrm{pH} 5$ and left in the refrigerator at $4^{\circ} \mathrm{C}$ for $8-12 \mathrm{~h}$. The acidified mixture was then centrifuged $\left(3500 \mathrm{rpm}, 4^{\circ} \mathrm{C}, 30 \mathrm{~min}\right)$, the precipitate was oven dried at $50^{\circ} \mathrm{C}$.

\subsection{Formulation of biscuit supplemented with moringa oleifera seed protein concentrate}

Moringa oleifera seeds protein concentrate (MSPC) were added to wheat flour (WF) at different proportions: Control (100 \% WF, 0\% MSPC); sample WMSP2 (98\% WF, 2\% MSPC); sample WMSP4 (96\% WF, 4\% MSPC) and sample WMSP6 (94\% WF, 6\% MSPC).

\subsection{Production of biscuit baking}

The biscuits were produced using a previously reported method [19]. Briefly, other ingredients (sugar, baking powder, water, baking fat and salt) were mixed with a mixture of wheat and Moringa seed protein concentrate flour. The fat was creamed with sugar until fluffy, the other dry ingredients were added, and water was added until the desired texture of the batter was obtained. The batter was kneaded on a rolling table to acquire the desired thickness. The batter was later cut to round shape with the aid of biscuit cutter. It was baked in the oven at $200^{\circ} \mathrm{C}$ for 10minutes, cooled and packaged

\subsection{Determination of proximate composition of moringa oleifera seeds protein concentrate flour and biscuit}

Proximate compositions (moisture content, ash, crude fibre, crude protein, and crude fat) of the protein concentrate and biscuit were determined using previously described method [20] while carbohydrate content was determined by difference

\subsection{Determination of amino acid profile of moringa oleifera seeds protein concentrate flour and biscuit}

The amino acid profile was determined following a previously reported method [21]. Samples were prepared for amino acid determination by acid hydrolysis. Hydrochloric acid (6 N) was used to hydrolyze the sample for 24 $\mathrm{h}$ at $110^{\circ} \mathrm{C}$ in a vial under vacuum and $\mathrm{N}_{2}$ atmosphere. The sample solution was evaporated and dissolved in sodium citrate buffer ( $\mathrm{pH}$ 2.2). The hydrolysates were analyzed by a post-column derivative method using a HPLC, which was combined with a Pickering PCX5200 derivatizer (Pickering Laboratories, Inc., USA) and ion exchange column $(3.0 \times 250 \mathrm{~mm}, 8 \mu \mathrm{m})$. The amino acids were spectrophotometrically identified by measuring at $570 \mathrm{~nm}$.

\subsection{Determination of mineral composition of moringa oleifera seed flour and biscuit}

This method is based on ion-exchange chromatography. At first, the samples were measured and heated at $800^{\circ} \mathrm{C}$ for $6 \mathrm{~h}$ in a muffle furnace. Then $2 \mathrm{~mL}$ conc. $\mathrm{HNO}_{3}$ was added to the sample and heated to evaporate. Then $10 \mathrm{~mL}$ conc. $\mathrm{HCl}$ was added and heated for $10 \mathrm{~min}$. The sample was then filtered and volume made up to $100 \mathrm{~mL}$. From the filtrate $10 \mathrm{~mL}$ was diluted again in a $100 \mathrm{~mL}$ volumetric flask. The sample was then analyzed by Thermo Scientific DionexIonpacTMICS-1600 column (4x250mm) based on ion-exchange chromatography.

\subsection{Microbiological assessment of concentrated protein and biscuit}

Each agar was prepared according to manufacturer's instruction for aerobic mesophilic count, yeast, mould and coliform count.

\subsection{Physical Properties of the Biscuit}


The physical properties were determined as previously reported [11]. The electronic weighing balance was used to take the weight, the Vernier caliper was used to measure the diameter and thickness of the biscuit. The Spread ratio (SR) was calculated by dividing the diameter over the thickness.

$$
S R=\frac{\text { diameter }}{\text { thickness }}
$$

\subsection{Statistical analyses}

All the data generated from the results were in triplicate, and subjected to analysis of variance (ANOVA). Means were tested for significances by Duncan's Multiple Range Test $(\mathrm{p}<0.05)$. Data are presented as mean \pm SD

\section{Results and discussion}

\subsection{Proximate composition of biscuit supplemented with moringa oleifera seed protein concentrate}

The proximate compositions of the control sample (100\% wheat biscuits, WF) and other samples supplemented with Moringa oleifera seed protein concentrate at 2\% (WMSP2), 4\% (WMSP4) and 6\% (WMSP6) are shown in Table 1. The data revealed high crude protein content in the concentrate (58\%). Supplementation of the biscuit with Moringa oleifera led to progressive but slight increase in the crude protein contents of the biscuits. This might be due to the marginal quantity of Moringa seed protein concentrate used in the supplementation. Previous studies on supplementation of biscuit with other protein sources had reported higher crude protein contents [4] but at higher supplementation level. Inclusion of Moringa seed protein flour could lead to higher protein content. Conversely, the supplementation led to a decrease in the carbohydrates content and expectedly, the energy value of the supplemented biscuits. Obviously, the decrease in carbohydrate content of the sample was due to the increased level of supplementation with the protein concentrate. At 6\% Moringa seed protein concentrate supplementation, the biscuits recorded the highest crude protein (12.98\%), crude fiber $(0.97 \%)$ and ash (2.86\%). These results were similar to previous study on crackers produced from blends of acha and pigeon pea [4]. The control sample had the highest carbohydrate content (71.02\%) while 6\% Moringa supplemented biscuit had the least carbohydrate content (66.94\%). This observation is in line with other studies that also reported low level of carbohydrate content of biscuit from wheat-maize-sesame flour blends [5]. The carbohydrate content (65.8872.54\%) of the Moringa supplemented biscuit samples produced in this study is within the range of the carbohydrate content (59.81-70.89\%) when compared to the previous result of biscuit samples produced from composite flour of wheat, maize and sesame flour blends [5].

The result of the physical characteristics of wheat biscuit and supplemented biscuits is also presented in Table 1. From the result, the diameter, weight and spread ratio of the biscuits increased with increase in Moringa seeds protein concentrate. Biscuits from 100\% wheat flour recorded the lowest weight, diameter and spread ratio of 10 $\mathrm{g}, 5.60 \mathrm{~cm}$ and $8.02 \mathrm{~cm}$ respectively while sample WMS6 had the highest value of $16 \mathrm{~g}, 6 \mathrm{~cm}$ and $10.71 \mathrm{~cm}$ respectively. The increase could be due to the removal of high oil content of the added Moringa oleifera seed, which agreed with previous findings [22]. Spread ratio or diameter is used to determine the quality of flour used in preparing biscuits and the ability of the biscuit to rise [23]. The higher the spread ratio of biscuit the more desirable it is [24]. The Moringa seed protein concentrate flour had a high and positive effect on the spread ratio. The inclusion of Moringa seed protein concentrate (MSPC) flour enhanced the spreadability of the biscuit samples and the level of substitution affected the ability of the biscuit to withstand stress. The spread ratio increased with increasing level of substitution with Moringa seed protein concentrate as the values varied from 8.02-10.71. The biscuits from $100 \%$ wheat had the lowest value of 8.02 while the biscuits from sample WMS6 recorded the highest value of 10.71 . Weight of the biscuits increased significantly $(p \leq 0.05)$ with increase in the amount of Moringa seed protein concentrate in the sample (10.02-16.01g) and this effect is applicable to diameter. The increase could be as a result of low fat content of Moringa seed protein concentrate. These results are similar to earlier observation [22] on cookies from sweet detar and Moringa leaf flour blend and [25] on cookies from Bambara groundnut. The difference in the observation could be because the other biscuits were produced from wheat flour that was substituted with legumes.

The moisture contents (2 - 3\%) of the supplemented biscuit and the control sample (2\%) were below the $10 \%$ moisture level which had been reported safe for keeping of flour samples [9] indicating good shelf stability of the products. Previous researchers had observed that lower moisture content of foods (less than 10\%) could contribute immensely to the keeping quality of such foods [25,26]. The crude fibre contents of the biscuit samples were observed to be generally low $(0.57-0.96 \%)$ though supplementation slightly increased the crude fibre content; this may be attributed to the low level of crude fibre in both wheat flour and Moringa seed protein concentrate flour used in the preparation of the biscuit. Ash is the aggregate of all non-volatile inorganic elements and an index of the mineral content of food. The increment in the ash content of the biscuit samples could probably be due to the 
higher supplementation level with Moringa seed protein concentrate. The ash content (0.97-2.86\%) obtained in this study is in line with the ash content (1.7-2.6\%) of cookies fortified with dried Moringa leaves [27].

Table 1. Proximate composition and physical characteristics of biscuit supplemented with Moringa oleifera seed protein concentrate

\begin{tabular}{llllll}
\hline SAMPLES & WF & WMSP2 & WMSP4 & WMSP6 & MSPC \\
\hline Protein & $10.52 \pm 0.10^{\mathrm{c}}$ & $10.96 \pm 0.11^{\mathrm{c}}$ & $12.60 \pm 0.30^{\mathrm{b}}$ & $12.98 \pm 0.10^{\mathrm{b}}$ & $57.92 \pm 0.10^{\mathrm{a}}$ \\
Moisture & $2.05 \pm 0.18^{\mathrm{c}}$ & $1.98 \pm 0.41^{\mathrm{d}}$ & $2.25 \pm 0.29^{\mathrm{c}}$ & $3.11 \pm 0.69^{\mathrm{b}}$ & $8.00 \pm 0.16^{\mathrm{a}}$ \\
Crude fibre & $0.57 \pm 0.10^{\mathrm{ab}}$ & $0.82 \pm 0.11^{\mathrm{ab}}$ & $0.94 \pm 0.11^{\mathrm{a}}$ & $0.97 \pm 0.10^{\mathrm{a}}$ & $0.32 \pm 0.12^{\mathrm{ab}}$ \\
Crude fat & $13.11 \pm 0.30^{\mathrm{b}}$ & $14.21 \pm 0.14^{\mathrm{a}}$ & $13.67 \pm 0.31^{\mathrm{ab}}$ & $13.35 \pm 0.33^{\mathrm{ab}}$ & $6.45 \pm 0.31^{\mathrm{c}}$ \\
Total ash & $1.30 \pm 0.34^{\mathrm{b}}$ & $2.24 \pm 0.32^{\mathrm{a}}$ & $2.58 \pm 0.32^{\mathrm{a}}$ & $2.86 \pm 0.10^{\mathrm{a}}$ & $0.97 \pm 0.10^{\mathrm{b}}$ \\
Carbohydrate & $71.02 \pm 0.61^{\mathrm{a}}$ & $70.03 \pm 0.27^{\mathrm{ab}}$ & $69.43 \pm 0.21^{\mathrm{b}}$ & $66.94 \pm 0.61^{\mathrm{c}}$ & $26.32 \pm 0.35^{\mathrm{d}}$ \\
Energy (kcal) & $454.65 \pm 3.69^{\mathrm{a}}$ & $446.02 \pm 2.72^{\mathrm{ab}}$ & $445.30 \pm 3.15^{\mathrm{ab}}$ & $438.98 \pm 3.83^{\mathrm{b}}$ & $395.13 \pm 1.22^{\mathrm{c}}$ \\
Weight(g) & $10.02 \pm 0.29^{\mathrm{d}}$ & $13.05 \pm 0.29^{\mathrm{c}}$ & $15.04 \pm 0.23^{\mathrm{b}}$ & $16.01 \pm 0.29^{\mathrm{a}}$ & \\
Thickness $(\mathrm{cm})$ & $0.70 \pm 0.15^{\mathrm{a}}$ & $0.67 \pm 0.21^{\mathrm{b}}$ & $0.60 \pm 0.21^{\mathrm{bc}}$ & $0.56 \pm 0.18^{\mathrm{c}}$ & \\
Diameter $(\mathrm{cm})$ & $5.60 \pm 0.29^{\mathrm{bc}}$ & $5.80 \pm 0.29^{\mathrm{bc}}$ & $5.82 \pm 0.25^{\mathrm{b}}$ & $6.00 \pm 0.20^{\mathrm{a}}$ & \\
Spread ratio & $8.02 \pm 0.22^{\mathrm{cd}}$ & $8.65 \pm 0.24^{\mathrm{c}}$ & $9.70 \pm 0.19^{\mathrm{b}}$ & $10.71 \pm 0.25^{\mathrm{a}}$ & \\
\hline
\end{tabular}

Values with different superscripts within the same row are significantly different ( $p \leq 0.05$ ).

Keys: $W F=100 \%$ Wheat flour, WMSP2 $=98 \%$ Wheat flour and $2 \%$ Moringa seed protein concentrate flour, WMSP $4=96 \%$ Wheat flour and 4\% Moringa seed protein concentrate flour, WMSP6 $=94 \%$ Wheat flour and 6\% Moringa seed protein concentrate flour, MSPC = Moringa seed protein concentrate.

\subsection{Amino acid profile of biscuit supplemented with moringa oleifera seed protein concentrate}

Table 2 shows the amino acid profile of biscuit supplemented with Moringa oleifera seed protein concentrate. The results revealed a concentration dependent increase on the amino acid with sample WMSP6 containing the highest values of all the amino acids, including the essential amino acids. Supplementation of the biscuits with $M$. oleifera seed protein concentrate significantly improved the amino acid contents when compared to the control sample (WF). Specifically, M. oleifera seed protein concentrate substantially increased the quantity of most of the essential amino acids which have been identified to be in lower concentrations in wheat flour and as confirmed in Table 2. In addition, it was observed that the essential amino acid values in WMSP6 were generally higher than the recommended FAO/WHO reference. This result therefore implies that the formulated biscuit contains appreciable amount of essential amino acid. This is particularly important as this is necessary for proper growth especially for children who are the major consumers of biscuits.

\subsection{Mineral composition of biscuit supplemented with moringa oleifera seed protein concentrate}

The mineral contents of wheat biscuit and biscuits supplemented with Moringa oleifera seed protein concentrate at $2 \%, 4 \%$ and $6 \%$ are given in Table 3 . Supplementation with $M$. oleifera seed protein concentrate only led to a marginal increases in the supplemented biscuits. The slight increase may also be due to the content of the minerals in the protein concentrate which is comparable to the control sample. Moringa seed powder has been reported to be rich in minerals that are essential for human development and growth [28]. Copper is required in the body for enzymes production and biological transfer of electron [29]. Low level of zinc and copper (0.05- 0.09 and 0.04$0.08 \mathrm{mg} / 100 \mathrm{~g}$ respectively recorded for the supplemented biscuits in this study could be as a result of low zinc and copper content in Moringa seed [30]. The calcium content (11.40-12.7 mg/100 g) of the Moringa supplemented biscuit reported in this study is higher than the calcium content $(1.24-1.98 \mathrm{mg} / 100 \mathrm{~g})$ of malted sorghum-soy biscuit [31]. The high calcium content of the biscuits produced in this study is an indication that the biscuits may promote bone development and strong teeth in children. Potassium and phosphorus are important component of cell and body fluids that help control heart beat rate and blood pressure [32]. The potassium content (12.90 -14.5 mg/100 g) of the supplemented Moringa seed protein concentrate biscuit reported in this study is higher than the potassium content $(4.60-6.20 \mathrm{mg} / 100 \mathrm{~g})$ of wheat-sweet potato biscuit [33]. The phosphorus content (15.8-17.5 mg/100 g) of the Moringa seed protein concentrate biscuit was higher than that of the unsupplemented biscuit $(14.6 \mathrm{mg} / 100 \mathrm{~g})$. Lead and cadmium are heavy metals whose presence are not desired in foods. Lack of these metals in the biscuits is an indication of its safety and fitness for consumption [30]. It implies that biscuits will not adversely affect the body system if consumed, especially with such illnesses resulting from consumption of heavy metals. In summary, these results suggest that biscuit of good mineral contents can be produced when wheat flour is supplemented with Moringa seed protein concentrate flour.

\subsection{Microbiological properties of biscuit supplemented with moringa oleifera seed protein concentrate}


Results of the microbiological analysis of the biscuit samples are shown in Table 4 . The results showed that the biscuit samples (100\% wheat, $2 \%, 4 \%$ and 6\% Moringa seed protein concentrate) contain 2, 2, 7 and 7 (10\%3/gm $\mathrm{cfu} / \mathrm{g}$ ) total viable count respectively which is significantly lower than the previous report for bread [34,35]. There was no yeast or mould detection for all the biscuit samples indicating that proper hygienic condition was maintained during the preparation and storage of the product. High temperature of the baking process may also have resulted in the values obtained. Therefore, the biscuit prepared by supplementing wheat flour and Moringa seed protein concentrate flour are microbiologically safe for human consumption.

Table 2. Amino acid profile (g/100 g) of biscuit supplemented with moringa oleifera seed protein concentrate

\begin{tabular}{|c|c|c|c|c|c|c|}
\hline Samples & WF & WMSP2 & WMSP4 & WMSP6 & MSPC & FAO/WHO (2007) \\
\hline \multicolumn{7}{|c|}{ Essential amino acids } \\
\hline Phenylalanine & $2.05^{\mathrm{b}}$ & $2.17^{b}$ & $4.00^{\mathrm{a}}$ & $4.09^{a}$ & $4.25^{\mathrm{a}}$ & 3.8 \\
\hline Histidine & $2.12^{b}$ & $2.24^{\mathrm{b}}$ & $3.90^{\mathrm{ab}}$ & $3.94^{\mathrm{ab}}$ & $4.03^{\mathrm{a}}$ & 1.5 \\
\hline Methionine & $1.23^{\mathrm{b}}$ & $1.34^{\mathrm{b}}$ & $2.75^{\mathrm{a}}$ & $2.81^{\mathrm{a}}$ & $2.94^{\mathrm{a}}$ & 1.6 \\
\hline Valine & $3.87^{\mathrm{bc}}$ & $4.02^{\mathrm{b}}$ & $5.00^{\mathrm{a}}$ & $5.08^{\mathrm{a}}$ & $5.20^{\mathrm{a}}$ & 3.9 \\
\hline Tryptophan & $3.87^{b}$ & $3.94^{b}$ & $5.07^{\mathrm{a}}$ & $5.13^{\mathrm{a}}$ & $5.23^{\mathrm{a}}$ & 0.6 \\
\hline Threonine & $2.20^{\mathrm{b}}$ & $2.41^{\mathrm{b}}$ & $3.84^{\mathrm{a}}$ & $3.99^{\mathrm{a}}$ & $4.10^{\mathrm{a}}$ & 2.3 \\
\hline Isoleucine & $1.86^{\mathrm{bc}}$ & $2.01^{\mathrm{b}}$ & $3.11^{\mathrm{a}}$ & $3.14^{\mathrm{a}}$ & $3.34^{\mathrm{a}}$ & 3.0 \\
\hline Leucine & $4.22^{\mathrm{b}}$ & $4.54^{\mathrm{b}}$ & $5.83^{\mathrm{ab}}$ & $5.95^{\mathrm{ab}}$ & $6.02^{\mathrm{a}}$ & 5.9 \\
\hline Lysine & $3.07^{b}$ & $3.16^{\mathrm{b}}$ & $6.07^{\mathrm{a}}$ & $6.14^{\mathrm{a}}$ & $6.57^{\mathrm{a}}$ & 4.5 \\
\hline SEAAs & $24.49^{d}$ & $25.83^{c}$ & $39.57^{b}$ & $40.27^{a b}$ & $41.68^{a}$ & \\
\hline \multicolumn{7}{|c|}{ Non-essential amino acids } \\
\hline Glycine & $2.08^{\mathrm{b}}$ & $2.17^{\mathrm{b}}$ & $4.15^{\mathrm{a}}$ & $4.20^{\mathrm{a}}$ & $4.30^{\mathrm{a}}$ & \\
\hline Alanine & $2.39^{b}$ & $2.60^{\mathrm{b}}$ & $4.51^{\mathrm{a}}$ & $4.60^{\mathrm{a}}$ & $4.85^{\mathrm{a}}$ & \\
\hline Serine & $2.80^{\mathrm{b}}$ & $2.95^{\mathrm{b}}$ & $3.80^{\mathrm{a}}$ & $3.88^{\mathrm{a}}$ & $3.96^{\mathrm{a}}$ & \\
\hline Proline & $1.59^{\mathrm{b}}$ & $1.81^{\mathrm{b}}$ & $3.00^{\mathrm{a}}$ & $3.04^{\mathrm{a}}$ & $3.14^{\mathrm{a}}$ & \\
\hline Aspartic & $6.82^{\mathrm{c}}$ & $7.01^{\mathrm{b}}$ & $8.00^{\mathrm{a}}$ & $8.11^{\mathrm{a}}$ & $8.84^{\mathrm{a}}$ & \\
\hline Cysteine & $0.23^{\mathrm{ab}}$ & $0.30^{\mathrm{ab}}$ & $0.48^{\mathrm{a}}$ & $0.52^{\mathrm{a}}$ & $0.61^{\mathrm{a}}$ & \\
\hline Glutamic & $9.83^{\mathrm{d}}$ & $10.04^{\mathrm{c}}$ & $11.17^{\mathrm{b}}$ & $11.45^{\mathrm{b}}$ & $12.06^{\mathrm{a}}$ & \\
\hline Tyrosine & $1.81^{\mathrm{b}}$ & $1.94^{\mathrm{b}}$ & $3.20^{\mathrm{a}}$ & $3.23^{\mathrm{a}}$ & $3.35^{\mathrm{a}}$ & \\
\hline Arginine & $4.00^{\mathrm{b}}$ & $4.11^{\mathrm{b}}$ & $6.06^{\mathrm{a}}$ & $6.10^{\mathrm{a}}$ & $6.24^{\mathrm{a}}$ & \\
\hline 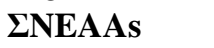 & $31.69^{\mathrm{e}}$ & $33.14^{d}$ & $44.53^{c}$ & $45.35^{b}$ & $47.66^{\mathrm{a}}$ & \\
\hline
\end{tabular}

Keys: $W F=100 \%$ Wheat flour, WMSP2 $=98 \%$ Wheat flour and $2 \%$ Moringa seed protein concentrate flour, WMSP4 $=96 \%$ Wheat flour and 4\% Moringa seed protein concentrate flour, WMSP6 = 94\% Wheat flour and 6\% Moringa seed protein concentrate flour.

Table 3. Mineral composition of biscuit supplemented with moringa oleifera seed protein concentrate

\begin{tabular}{llllll}
\hline Samples(mg/100g) & WF & WMS2 & WMS4 & WMS6 & MSPC \\
\hline Sodium & $33.80^{\mathrm{d}}$ & $34.50^{\mathrm{c}}$ & $35.20^{\mathrm{a}}$ & $36.40^{\mathrm{a}}$ & $35.70^{\mathrm{a}}$ \\
Potassium & $12.40^{\mathrm{c}}$ & $12.90^{\mathrm{c}}$ & $13.70^{\mathrm{b}}$ & $14.50^{\mathrm{a}}$ & $14.10^{\mathrm{a}}$ \\
Calcium & $10.80^{\mathrm{c}}$ & $11.40^{\mathrm{b}}$ & $12.10^{\mathrm{a}}$ & $12.70^{\mathrm{a}}$ & $12.30^{\mathrm{a}}$ \\
Magnesium & $11.70^{\mathrm{d}}$ & $12.20^{\mathrm{c}}$ & $13.40^{\mathrm{b}}$ & $14.20^{\mathrm{a}}$ & $13.70^{\mathrm{b}}$ \\
Phosphorus & $14.60^{\mathrm{d}}$ & $15.80^{\mathrm{c}}$ & $16.90^{\mathrm{b}}$ & $17.50^{\mathrm{a}}$ & $17.20^{\mathrm{a}}$ \\
Copper & $0.04 \mathrm{a}$ & $0.05^{\mathrm{a}}$ & $0.07^{\mathrm{a}}$ & $0.08^{\mathrm{a}}$ & $0.07^{\mathrm{a}}$ \\
Zinc & $0.05^{\mathrm{a}}$ & $0.06^{\mathrm{a}}$ & $0.08^{\mathrm{a}}$ & $0.09^{\mathrm{a}}$ & $0.08^{\mathrm{a}}$ \\
Lead & ND & ND & ND & ND & ND \\
Cadmium & ND & ND & ND & ND & ND \\
\hline
\end{tabular}

Keys: $W=100 \%$ Wheat flour, WMSP2 $=98 \%$ Wheat flour and $2 \%$ Moringa seed protein concentrate flour, WMSP $4=96 \%$ Wheat flour and 4\% Moringa seed protein concentrate flour, WMSP6 =94\% Wheat flour and 6\% Moringa seed protein concentrate flour.

\subsection{Sensory qualities of biscuit supplemented with moringa oleifera seeds protein concentrate}

The sensory properties of biscuit produced from wheat and the supplemented wheat biscuit are shown in Table 5. Biscuits produced from $100 \%$ wheat (control) were rated higher in appearance and taste when compared to other 
biscuit samples. This result could be due to the familiarities of the panelist with the wheat flour biscuit. Increase in the level of Moringa seed protein concentrate flour in the samples increased the aroma of the biscuits by the panelists. While general familiarity and wide acceptance of wheat biscuits by the panelists may have resulted in higher ranking of some of the sensory qualities evaluated, the overall acceptability indicated that there was not much disparity (7.23 - 7.38) among the samples.

Table 4. Microbiological properties of biscuit supplemented with moringa oleifera seed protein concentrate

\begin{tabular}{lllll}
\hline Microorganisms & WF & WMS2 & WMS4 & WMS6 \\
\hline Total viable count $\left(10^{3} \mathrm{cfu} / \mathrm{g}\right)$ & 2 & 2 & 7 & 7 \\
Coliform $\left(10^{3} / \mathrm{g}\right)$ & $\mathrm{Nil}$ & $\mathrm{Nil}$ & $\mathrm{Nil}$ & $\mathrm{Nil}$ \\
Yeast and mould $\left(10^{3} \mathrm{cfu} / \mathrm{g}\right)$ & $\mathrm{Nil}$ & $\mathrm{Nil}$ & $\mathrm{Nil}$ & $\mathrm{Nil}$ \\
\hline
\end{tabular}

Keys: $W F=100 \%$ Wheat flour, WMSP2 $=98 \%$ Wheat flour and $2 \%$ Moringa seed protein concentrate flour, WMSP4 $=96 \%$ Wheat flour and 4\% Moringa seed protein concentrate flour, WMSP6 $=94 \%$ Wheat flour and 6\% Moringa seed protein concentrate flour.

Table 5. Sensory qualities of biscuit supplemented with moringa oleifera seed protein concentrate

\begin{tabular}{lllll}
\hline Samples & WF & WMSP2 & WMSP4 & WMSP6 \\
\hline Appearance & $7.38 \pm 0.18^{\mathrm{a}}$ & $7.30 \pm 0.41^{\mathrm{a}}$ & $7.15 \pm 0.22^{\mathrm{a}}$ & $7.21 \pm 0.24^{\mathrm{a}}$ \\
Taste & $6.54 \pm 0.41^{\mathrm{a}}$ & $6.50 \pm 0.38^{\mathrm{a}}$ & $6.55 \pm 0.47^{\mathrm{a}}$ & $6.95 \pm 0.48^{\mathrm{a}}$ \\
Crispness & $7.10 \pm 0.20^{\mathrm{a}}$ & $7.15 \pm 0.30^{\mathrm{a}}$ & $6.76 \pm 0.39^{\mathrm{a}}$ & $6.92 \pm 0.37^{\mathrm{a}}$ \\
Aroma & $7.03 \pm 0.48^{\mathrm{a}}$ & $7.07 \pm 0.29^{\mathrm{a}}$ & $7.15 \pm 0.11^{\mathrm{a}}$ & $7.30 \pm 0.40^{\mathrm{a}}$ \\
Overall acceptability & $7.38 \pm 0.24^{\mathrm{a}}$ & $7.38 \pm 0.32^{\mathrm{a}}$ & $7.23 \pm 0.17^{\mathrm{a}}$ & $7.30 \pm 0.37^{\mathrm{a}}$ \\
\hline
\end{tabular}

Values with different superscripts within the same column are significantly different ( $p \leq 0.05$ ).

Keys: $W=100 \%$ Wheat flour, WMSP2 $=98 \%$ Wheat flour and 2\% Moringa seed protein concentrate flour, WMSP $4=96 \%$ Wheat flour and 4\% Moringa seed protein concentrate flour, WMSP6 $=94 \%$ Wheat flour and 6\% Moringa seed protein concentrate flour.

\section{Conclusions}

This study was carried out in order to test for the nutritional and sensory qualities of biscuit produced from wheat and Moringa seed protein concentrate flour. The supplementation of biscuit with Moringa seed protein concentrate led to improved nutritional qualities (crude protein content, amino acid profile and mineral element composition). This may be essential for the growth and development of children who are the major consumers of biscuits.

\section{References}

[1] Masoodi L, Bashir V. Fortification of biscuit with flaxseed: biscuit production and quality evaluation. IOSR J Environ Sci Toxicol Food Technol. 2012;1(2):06-09.

[2] Pasqualone A, Makhlouf FZ, Barkat M, Difonzo G, Summo C, Squeo G, Caponio F. Effect of acorn flour on the physico-chemical and sensory properties of biscuits. Heliyon. 2019;5(8):e02242.

[3] Mahloko LM, Silungwe H, Mashau ME, Kgatla TE. Bioactive compounds, antioxidant activity and physical characteristics of wheat-prickly pear and banana biscuits. Heliyon. 2019;5(10):e02479.

[4] Olagunju AI, Omoba OS, Enujiugha VN, Aluko RE. Development of value-added nutritious crackers with high antidiabetic properties from blends of Acha (Digitaria exilis) and blanched Pigeon pea (Cajanus cajan). Food Science \& Nutrition. 2018;6(7):1791-1802.

[5] Rai BS, Shukla S, Kishor K, Singh H, Dey S. Quality characteristics of biscuits produced from composite flour of wheat, maize and sesame seed. Journal of Pharmacognosy and Phytochemistry. 2017;6(4):2011-2015.

[6] Jariyah J, Widjanarko SB, Estiasih T. Quality evaluation of wheat-pedada fruit flour (PFF) biscuit with different emulsifiers. Agriculture and Agricultural Science Procedia. 2016;9:518-524.

[7] Awolu OO. Optimization of the functional characteristics, pasting and rheological properties of pearl milletbased composite flour. Heliyon. 2017;3(2):e00240.

[8] Aderinola TA, Allikura OJ. Qulaity evaluation of cookies from wheat and breadfruit composite flour. Ann. N. Y. Acad. Sci. 2015;16:354-358.

[9] Bamigbola YA, Awolu OO, Oluwalana IB. The effect of plantain and tigernut flours substitution on the antioxidant, physicochemical and pasting properties of wheat-based composite flours. Cogent Food \& Agriculture. 2016;2(1):1245060. 
[10] Ameh MO, Gernah DI, Igbabul BD. Physico-chemical and sensory evaluation of wheat bread supplemented with stabilized undefatted rice bran. Food and Nutrition Sciences. 2013;4(09):43-48.

[11] Ayo JA, Ayo VA, Nkama I, Adewori R. Physiochemical, in-vitro digestibility and organoleptic evaluation of "Acha" wheat biscuit supplemented with soybean flour. Nigerian Food Journal. 2007;25(1):77-89.

[12] Awolu OO, Omoba OS, Olawoye O, Dairo M. Optimization of production and quality evaluation of maizebased snack supplemented with soybean and tiger-nut (Cyperus esculenta) flour. Food Science \& Nutrition. 2017;5(1):3-13.

[13] Sultana A, Amin MN, Miah MY, Sarker AK, Rasel MMA, Aziz MT, Sharmin F, Hakim MA, Shiddika H, Emon SH, Tuli TP, Khanom MM. Determination of proximate composition and amino acid profile of jackfruit seed and utilization of its seed flour for development of protein enriched supplementary food. Cell Biol. 2017;5:57.

[14] Abiodun OA, Adegbite JA, Omolola AO. Chemical and physicochemical properties of Moringa flours and oil. Glob. J. Sci. Front. Res. 2012;12(5):13-17.

[15] Aderinola TA, Fagbemi TN, Enujiugha VN, Alashi AM, Aluko RE. In vitro antihypertensive and antioxidative properties of alcalase-derived Moringa oleifera seed globulin hydrolysate and its membrane fractions. Journal of Food Processing and Preservation. 2019;43(2):e13862.

[16] Aderinola TA, Fagbemi TN, Enujiugha VN, Alashi AM, Aluko RE. Amino acid composition and antioxidant properties of Moringa oleifera seed protein isolate and enzymatic hydrolysates. Heliyon. 2018;4(10):e00877.

[17] Aderinola TA, Fagbemi TN, Enujiugha VN, Alashi AM, Aluko RE. In vitro antihypertensive and antioxidative properties of trypsin-derived Moringa oleifera seed globulin hydrolyzate and its membrane fractions. Food Science \& Nutrition. 2019;7(1):132-138.

[18] Aderinola TA, Alashi AM, Nwachukwu ID, Fagbemi TN, Enujiugha VN, Aluko RE. In vitro digestibility, structural and functional properties of Moringa oleifera seed proteins. Food Hydrocolloids. 2020;101:105574.

[19] Omachi DO, Yusufu PA. Physico-chemical , sensory and microbiological assessment of millet based biscuits improved with cashew nuts (Anarcadium Occidentale), carrot flour (Daucus Carota). Am. J. Food Nutr. 2017;7:13-22.

[20] AOAC, Association of Analytical Chemists International. Official methods of analysis of AOAC, 19 th ed. Gaithersburg, MD, USA; 2012.

[21] Awolu OO, Omoba OS, Olawoye O, Dairo M. Optimization of production and quality evaluation of maizebased snack supplemented with soybean and tiger-nut (Cyperus esculenta) flour. Food Science \& Nutrition. 2017;5(1):3-13.

[22] Igbabul B, Ogunrinde MD, Amove J. Proximate, micronutrient composition, physical and sensory properties of cookies produced with wheat, sweet detar and moringa leaf flour blends. Current Research in Nutrition and Food Science Journal. 2018;6(3):690-699.

[23] Bala A, Gul K, Riar CS. Functional and sensory properties of cookies prepared from wheat flour supplemented with cassava and water chestnut flours. Cogent Food \& Agriculture. 2015;1(1):1019815.

[24] Chauhan A, Saxena DC, Singh S. Physical, textural, and sensory characteristics of wheat and amaranth flour blend cookies. Cogent Food \& Agriculture. 2016;2(1):1125773.

[25] Adegbanke OR, Ojo-uyi DO, Oluwajuyitan TD. Application of bambara groundnut in the production of cookies. Food Science and Quality Management. 2019;83:56-60.

[26] Ibrahim SM. Evaluation of production and quality of salt-biscuits supplemented with fish protein concentrate. World Journal of Dairy and Food Sciences. 2009;4(1):28-31.

[27] Youssef HM. Assessment of gross chemical composition, mineral composition, vitamin composition and amino acids composition of wheat biscuits and wheat germ fortified biscuits. Food and Nutrition Sciences. 2015;6(10):845-853.

[28] Mahmood KT, Mugal T, Haq IU. Moringa oleifera: a natural gift-A review. Journal of Pharmaceutical Sciences and Research. 2010;2(11):775-781.

[29] Adeleke RO, Odedeji JO. Acceptability studies on bread fortified with Tilapia fish flour. Pakistan Journal of Nutrition. 2010;9(6):531-534.

[30] Sodamade A. Nutrient contents and mineral composition of moringa oleifera seed. Int. J. Chem. Stud. 2017;5: 205-207.

[31] Bolarinwa IF, Abioye AO, Adeyanju JA, Kareem ZO. Production and quality evaluation of biscuits produced from malted sorghum-soy flour blends. Journal of Advances in Food Science \& Technology. 2016;3(3):107113.

[32] Bolarinwa IF, Aruna TE, Raji AO. Nutritive value and acceptability of bread fortified with moringa seed powder. Journal of the Saudi Society of Agricultural Sciences. 2019;18(2):195-200.

[33] Onabanjo OO, Ighere DA. Nutritional, functional and sensory properties of biscuit produced from wheatsweet potato composite. Journal of Food Technology Research. 2014;1(2):111-121. 
[34] Ijah UJ, Auta HS, Aduloju MO, Aransiola SA. Microbiological, nutritional, and sensory quality of bread produced from wheat and potato flour blends. International Journal of Food Science. 2014;2014: 671701.

[35] Khanom A, Shammi T, Kabir MS. Determination of microbiological quality of packed and unpacked bread. Stamford Journal of Microbiology. 2016;6(1):24-29.

(c)

(C) 2020 by the author(s). This work is licensed under a Creative Commons Attribution 4.0 International License (http://creativecommons.org/licenses/by/4.0/). Authors retain copyright of their work, with first publication rights granted to Tech Reviews Ltd. 